\title{
CORPORATE BOARD COMPOSITION IN FAMILY BUSINESSES: EVIDENCE FROM THE CZECH REPUBLIC
}

\author{
Pavla Odehnalová* \\ Petr Pirožek**
}

Received: 5. 3. 2018

Case study

Accepted: 27. 11. 2018

UDC 334.722.24:174(437.3)

DOI https://doi.org/10.30924/mjcmi/2018.23.2.155

\begin{abstract}
This paper examines the issue of board composition of family businesses which were established in the Czech Republic in the 1990s, after more than 40 years of private enterprises being forcefully suspended by the socialist regime. So far, there has been no available research investigating manufacturing sector in the Czech Republic (CR) from the perspective of board composition, i.e. the representation of external members and gender diversity, on the characteristic behaviours of the boards of family businesses and their strategic adaptability. This longitudinal study of four family businesses provides valuable information which have not yet been observed against the background of board composition in the manufacturing sector. The
\end{abstract}

\section{INTRODUCTION}

Corporate governance represents a significant factor determining the long-term prosperity of business activities of family firms (Banalieva et al., 2014; Brunninge et al., 2007) in countries with a short modern history of family enterprises such as the Czech Republic. Family enterprises had a long tradition in what is now the Czech results of the interviews conducted in these businesses yield interesting findings about the fact that gender diversity along with the exclusive representation of family members on a corporate board has a very positive influence on strategic adaptability and an impact on the current direction of the business. The results of the study also show how family businesses fulfilling these conditions are better able to cope with negative external influences (e.g. the financial crisis).

Keywords: board composition, family business, transition economy, corporate governance, gender, nepotism, paternalism, strategic adaptability.

Republic, beginning in the $16^{\text {th }}$ and $17^{\text {th }}$ centuries with the economic activities of noble families (Čornej, 1992). However, the real turning point for family enterprises came with the onset of socialism in the 1940s, when all the factories were nationalized. The rise of socialism with the implementation of planned economy in the Central and Eastern Europe (CEE) states and in the

\footnotetext{
* Pavla Odehnalová, Ph.D., Department of Corporate Economy, Faculty of Economics and Administration, Masaryk University, Lipová 41a, Brno, 602 00, Czech Republic, e-mail: odehnalova@mail.muni.cz, phone: +420549495058 ** Petr Pirožek, Ph.D., Department of Corporate Economy, Faculty of Economics and Administration, Masaryk University, Lipová 41a, Brno, 602 00, Czech Republic, e-mail: 102532@mail.muni.cz, phone: +42054949 4783
} 
Czech Republic meant the total eradication of family enterprises. The tradition of family firms built up over many years was itself completely disrupted by the nationalization of property.

Corporate governance of family firms with a violently interrupted and negative history of entrepreneurship in CEE states has not yet been given sufficient attention, despite the fact that the structure of bodies, their activities and role greatly influence the day-to-day running of the family business (FB) and its performance (Corbetta \& Salvato, 2004). This applies not only to the Czech Republic but also to all of the CEE countries that have undergone the difficult period of transformation of the economy (Smallbone \& Welter, 2001).

The aim of this paper is to present board compositions of family businesses with characteristic behaviours which arose in the manufacturing sector in the Czech Republic and show how the current direction of family businesses caused by characteristic behaviours influences the strategic adaptability.

\section{THEORETICAL BACKGROUND}

The issue of corporate governance has been described extensively, mostly in relation to larger companies, both in terms of maximizing value for shareholders (Fama, 1980) and associated activities within the exercise of ownership rights (Fama \& Jensen, 1983), sometimes involving external financing of companies listed on the stock exchange (Shleifer \& Vishny, 1997). The administration of family companies has been well-documented, especially in environments with long-term, stable development (Ponomareva \& Ahlberg, 2016; García-Ramos \& García-Olalla, 2011;
Gomez-Mejia et al., 2001), which is especially characteristic of countries with a developed market economy. The creation of boards consisting of family member in the Czech Republic in the 1990s was therefore entirely spontaneous, without any influence from findings regarding the advantages and limitations of family businesses, which were unknown in the Czech Republic at that time.

In this paper we consider a family firm to be a business organization in which the members of one or more families, who also run the company, have the controlling interest. "Family involvement in entrepreneurship assumes that at least two family members work in the firm" (Sten, 2007). Family firms examined can therefore be defined as companies in which at least two members of one family work in and have a direct influence on the running of the firm (Taguiry \& Davis, 1996). Behaviours of boards of family firms can be described by the characteristics which determine the long-term development and strategic adaptability of these companies. Strategic adaptability is defined as a cushion of actual or potential resources which allows an organization to adapt successfully to internal pressures for adjustment or to external pressures for changes in policy as well as to initiate changes in strategy with respect to the external environment (McKee et al., 1989).

\subsection{Basis of the composition and structure of the bodies of family firms}

Current knowledge regarding the appropriate corporate governance structure in business corporations emphasizes the influential aspect linked with board independence (Aguilera \& Cuervo-Cazzura, 2004) represented by a higher proportion of external board members. In countries in the post-transformation phase of the market 
economy, where no family firms have a modern business history lasting more than 25 years, it is still possible to encounter a generally prevailing concept of supervision over the company by family representatives (Lane et al., 2006). This is mainly due to trust (Gomez-Mejia et al., 2001) and preferences for other family members (Collin \& Ahlberg, 2012). However, it is also possible to detect some negative factors linked, for example, with rivalry and conflicts between family members (Tagiuri \& Davis, 1996), which demonstrates that a pure representation of family representatives on the board of family firms is not a mandatory standard.

Unfortunately, no study on gender diversity in the bodies of family firms has been conducted yet and its impact on the direction of the business, which has undergone a transformation in recent times. This points to a gap in research into the board composition of family businesses founded in the transition economy in terms of the representation of external top managers on boards as well as the representation of women on the boards of family businesses. On the basis of these findings, the following research question can be formulated:

RQ1: What is the typical board composition of FBs founded in the transition economy?

\subsection{Characteristic behaviours of the boards of family businesses}

In general, the behaviour of family businesses can be viewed as a system of appointments in which preference is given to relatives over other, frequently better qualified candidates (Bellow, 2003). Nepotism thus represents the imagined consequences of the predominance of family logic over corporate rationality (Kets de Vries, 1996). In the past, nepotism was often perceived as a negative phenomenon. Companies in which nepotism manifests itself often have a problem retaining capable external workers, who leave as a result of the incompetence of the leadership of the family firm exercised by family representatives . For regular employees of the company who are not family members, the inability to manage the company and the associated lack of authority can have a very demotivating effect, leading to a disruption to the corporate climate, dissatisfaction with the work carried out, and a consequent reduction in work motivation and performance (Kets de Vries, 1996; Nelton, 1998).

Nevertheless, despite the general perception of nepotism as a negative phenomenon for family businesses, there are well-known studies describing family firms which practise nepotism and do not suffer a decline in corporate performance in the long run -the performance of some even exceeds the sector average (Anderso \& Reeb, 2004; Miller et al., 2011).

Some studies (Jaskiewicz et al., 2013; Anderson \& Reeb, 2004; Miller et al., 2011) point out that nepotism can also be beneficial to a family company. If the family is in danger of losing its property through a transfer of the controlling interest to an external employee, family firms tend to choose a board member from the ranks of the family ( $\mathrm{Lin} \& \mathrm{Hu}, 2007$ ), thereby preventing the loss of ownership of the company; this is probably why research focusing on "stewardship in family firms" (Anderson \& Reeb, 2003; Miller \& Le Breton-Miller, 2005) highlights the benefits of "continuous family ownership", which can enhance company's performance, its long-term orientation and also its strategic adaptability.

Within this context, Jaskiewicz et al. (2013) define two types of nepotism: entitlement nepotism and reciprocal nepotism. Entitlement nepotism is perceived as a 
negative form of nepotism, which is linked with the involvement of an unqualified or badly prepared "nepot" (eng. descendant) in the business practice. This form of nepotism can manifest itself both in lower to middle management and in the highest positions, i.e. in the firm's statutory bodies or even in the position of the company director. An ill-advised change in the company's management influenced by nepotism which fails to achieve the corporate goals can ultimately lead to the demise of the family firm (Nelton, 1998; Kets de Vries, 1996). The existence of entitlement nepotism is also supported by the fact that only one third of family firms survive the transition from one generation to the next (Tyee, 2007).

On the other hand, Jackiewicz et al. (2013) see the success of family firms that make use of reciprocal nepotism as being due to "transfer of tacit knowledge" (Nonaka, 1994; Gatarik \& Born, 2015), which is considered (Coff et al., 2006 and Matusik \& Hill, 1998) to be one of the key elements in the company's competitiveness and performance. This results in a concept of family enterprise in which it is very difficult for the external environment to access or imitate tacit knowledge in the form of a unique know-how. This kind of know-how conceived as "personal, context-specific and acquired by experience" (D'Eredita \& Barreto, 2006: 1824), is the privilege of people who have personal experience of utilizing it (Turner \& Makhija, 2006). Reciprocal nepotism, which enables the transfer of tacit knowledge from generation to generation within the board, may be one of the factors which supports the sustainability of the company in the hands of the family (Miller \& Le Breton-Miller, 2015; Collin \& Ahlberg, 2012) and thereby also increases the strategic adaptability of the business to external influences of the environment (Ponomareva \& Ahlberg, 2016).
In addition to the transfer of tacit knowledge, another factor supporting the orientation towards maintaining the company is the board members' attitude to risk. Jaffe \& Lane (2004) state that family firms (dynasties) often work on the principle of deep moral and spiritual values with the aim of keeping property in the hands of the family in the long run and maintaining the company independent of the surrounding environment. This is probably another reason why family firms are more averse to risk compared to non-family firms (Naldi et al., 2007).

Family firms' aversion to risk has been demonstrated by a number of studies (Donckels \& Frohlich, 1991; Zahra, 2005) and is frequently related to the company ownership and the corporate governance structure applied in the family firm. Families often make a substantial investment in their family firms and thus bear the full risk of a poor investment (Naldi et al., 2007; Gedajlovic et al., 2004). Therefore, if we proceed from the findings of the abovementioned authors, it can be assumed that the greater the family's ownership rights in the family firm, the fewer risks they will take. This manifests itself in a lower orientation towards growth, a general conservativeness in the business practice (Donckelse \& Fröhlich, 1991) and an orientation towards the long-term sustainability of the company (Jaffe \& Lane, 2004; Miller \& Le Breton-Miller, 2015; Collin \& Ahlberg, 2012) connected with the strategic adaptability (Ponomareva \& Ahlberg, 2016; McKee et al., 1989) of family businesses.

During the exercise of corporate governance, family firms often have to contend with the issue of paternalism. Typical features of paternalism exhibited in the leadership of a family firm include an inclination towards autocracy, a strong need for 
control, a lack of trust in other co-workers, a need for recognition and an inability to delegate (Kets de Vries, 1996; Mussollino \& Calabro, 2014). Here paternalism is perceived as a protective and dominant ideology (Koiranen, 2004). In the early stages the founder's autocratic behaviour leads to good results for the family firm, which is manifested in its growth. The associated long-term orientation of family members on the board represents a considerable competitive advantage (Coff et al., 2006; Matusik \& Hill, 1998; Miller \& Le Breton-Miller, 2015; Collin \& Ahlberg, 2012). An orientation towards maintaining the company is typical of family firms and is closely related to trust and risk aversion. The trust exhibited in family businesses strengthens stakeholders' faith that family firms will honour their commitments. Trust also strengthens mutual cooperation and interpersonal relations, reduces the threat of conflict, lowers transaction costs and facilitates effective conflict resolution, thereby supports the running of the company (Sundaramurthy, 2008; Rousseau et al., 1998). The strength of mutual relations can then motivate individuals to take more responsibility for their actions - in this case, their work in the family firm. However, when a situation arises where an incoming family member assumes a major role on the board, the negative side of paternalistic behaviour often manifests itself too. The original owner/ founder exhibits mistrust towards incoming board members in the form of constant control. The autocratic behaviour of the original founder predominates over the behaviour of the new management (Mussolino \& Calabro, 2014; Sharma et al., 2003). The situation often causes an increased lack of clarity in executive decision-making and leads to disputes over jurisdiction with a negative impact on employees (Nelton, 1998). Similarly, Dyer (1986) and Mussolino \& Calabro (2014) state that family leaders retain all the essential information and decision-making powers in their own hands.

\subsection{Direction and impact on the strategic adaptability of family businesses}

The board of a family firm can be regarded as a complex arrangement both from the legislative viewpoint and from the viewpoint of the social and psychological arrangement (Bettinelli, 2011; Collin \& Ahlberg, 2012). An awareness of the "ownership" of the company entails certain rights and responsibilities (Koiranen, 2002). It is this responsibility for the company which motivates the founder to engage in a conduct which is effective in the long run by employing strategies oriented towards the long-term future (Le Breton-Miller \& Miller, 2015; Jaskiewicz et al., 2013). Le Breton-Miller \& Miller (2006) define longterm orientation as priorities, goals and concrete investments that come to fruition over an extended time period. The question remains whether strategies influenced by spontaneously arising characteristics typical of the behaviour of family businesses will affect the direction of the business positively or negatively in the long run. According to Le Breton-Miller \& Miller (2006) longterm strategies include good stewardship aimed at reducing risk, investing in people and knowledge, enduring relationship with stakeholders. These investments can be observed as the characteristic behaviours presented by the relationship towards risk (Naldi et al., 2007), nepotism (Jaskiewicz et al., 2013), paternalism (Mussolino \& Calabro, 2014; Sharma et al., 2003), centralization, orientation towards sustainability (Sundaramurthy, 2008; Rousseau et al., 1998, Le Breton-Miller \& Miller, 2006).

The evaluation of this impact from the viewpoint of strategic adaptability can be 
assessed, for example, by the retention of the company in the family's possession (Bettinelli, 2011; Fama \& Jensen, 1983), by indebtedness (Carney, 2005) or by the financial ratio ROA (McKee et al., 1989).

RQ2: What are the characteristic behaviours of the board of a family business with regard to their long-term strategy?

\subsection{Research design}

The research focuses on the period of transformation of the economy including the period associated with the post-transformation phase of the development of family businesses. The time frame of the transformation period is quite clearly defined by the beginning of the conversion of the planned economy into a market economy and bounded by the year 1989 or 1990 . It is difficult to define the end of the transformation period and the beginning of the posttransformation period; nevertheless, some authors (Žídek, 2006) dealing with the issue of transformation set the end of the transformation of the Czech economy into a market economy as the Czech Republic's accession to the European Union and with that the fulfilling of the conditions for the operation of the principles of the market economy, i.e. the year 2004. This is subsequently reflected in the framework for staging the research.

\section{METHODOLOGY}

Based on the internal characteristics of the board, which are primarily the result of sociological factors, the performance of the companies and their capability for sustainability on the market over a period of 10 years were monitored. The research we carried out on a sample of several family firms also covers research into social relations, which is rather subjective in nature and necessitated the use of qualitative techniques.

\subsection{Sampling}

the research was carried out between 2006 and 2015, when in the initial part of the research 91 family firms were identified from the Albertina database of businesses from the manufacturing industry in the CR (432 companies) on the basis of certain criteria satisfying the definition of family business. All the companies in Albertina database had to fulfil the following conditions: have publicly available financial statement and specifically, at least two family members had to be directly involved in the running of the business and at the same time also work in the family firm (Odehnalová, 2008, according to Lukeš \& Nový, 2005; Sten, 2007).

Following on from the established research questions RQ1, RQ2, businesses fulfilling the conditions outlined below were selected from the database based and contacted. In light of the aforementioned basis for the research and the research questions, we opted for the multiple case study method. The reason for this was that multiple case studies typically provide a stronger base for explanation (De Massis \& Kotlar, 2014). Therefore, case studies with different board composition were chosen so as to make it possible to investigate characteristic phenomena and their impact on business's longterm strategies and strategic adaptability. For an appropriate configuration of the selected sample of family firms covering the required phenomena under research, the following conditions for defining the sample to answer the research questions were set:

1. Businesses which had more than one member of a family on the board, so as to ensure, among other things, that the definition of a family business was met.

2. Businesses that represent various sectors, i.e. mechanical engineering, 
construction and the manufacturing industry.

3. Businesses where the representation of family members on boards was as diverse as possible.

4. Businesses where another member of the family was also employed in a nonmanagerial position, in order to determine the influence on long-term functioning and the strategies applied.

5. Businesses that have been on the market for some time and have a healthy economic situation, so as to be able to monitor them over as long a period as possible - their economic situation was good, so they could be expected to survive for the foreseeable future, making it possible to study their long-term strategy, strategic adaptability and the related impact on the direction of the businesses.

\subsection{The approach to data analysis}

The first stage of the research was based on reading the literature from the secondary sources, specifically the business databases Albertina and justice.cz that provide information on the industry sector the company belonged to, the year of its establishment, the number of employees, the number of family members represented in the company board and gender diversity of the board . This information was used as the basis for answering RQ1.
In order to answer RQ2, the company representatives were provided with a questionnaire focusing on company's position in the market from the perspective of their ownership structure, the characteristic phenomena in the family business and their influence on developing strategy.

In order to provide the missing information and answer RQ2 a field study was carried out on a sample of four family businesses. The firms were visited by the same researcher in the years 2011 and 2012 after prior telephone arrangement with the firms' managers, which involved a brief explanation of the research objectives and how long the interview would last to collect the necessary, relevant data. The interviews lasted between 1 and 2 hours, while one was longer and lasted 3 hours as the company manager insisted it was necessary to visit the entire firm. The interviews took place on company grounds. The interviews were always attended by one of the firm's owners, who was also a family representative. The information gathered during the interviews were supplemented by other information concerning the interview procedure, the respondents' behaviour and their gestures and comments. The transcript for the interviews from all companies had 68 pages. The transcription, categorization and data coding were all carried out by the same researcher. Subsequently, for the purpose of evaluation

Table 1. Cooperating family firms

\begin{tabular}{|l|l|l|l|l|l|}
\hline \multicolumn{1}{|c|}{ Business } & $\begin{array}{c}\text { Activity according to } \\
\text { CZ - NACE }\end{array}$ & Year founded & $\begin{array}{c}\text { Number of } \\
\text { employees }\end{array}$ & $\begin{array}{c}\text { \% of family } \\
\text { members in the } \\
\text { board }\end{array}$ & $\begin{array}{c}\text { Gender } \\
\text { diversity }\end{array}$ \\
\hline Firm A & C. 31 & 1991 & 96 & $100 \%$ & no \\
\hline Firm B & F.41 & 1992 & 110 & $100 \%$ & yes \\
\hline Firm C & C. 25 & 1996 & 83 & $100 \%$ & yes \\
\hline Firm D & F. 42 & 1994 & 65 & $33 \%$ & no \\
\hline
\end{tabular}

Source: authors according to internal materials of the observed companies 
another researcher was brought in so that the categorization and coding could be carried out independently, thereby ensuring impartial evaluation of data (Miles \& Huberman, 1994). Second researcher's notes on the categorization and coding were then incorporated into the research, thus contributing to it.

In order to answer RQ 2, the firms were subsequently observed on the basis of identifying characteristics (presented in the theoretical section) which influenced the strategy of the family business over the following years, while year-on-year information on any changes to the board composition was recorded from the Albertina database and basic financial indicators of strategic adaptability, such as ROA and indebtedness were evaluated. An evaluation of the impact of the strategy on the current direction of companies and the associated behaviour of the observed family-business boards was done using a standard indicator for company performance - ROA (McKee et al., 1989). Due to the importance of indebtedness in the Czech Republic as a result of the transformation period of the economy and the associated lack of financial resources (Suchánek et al., 2011), we also used an indicator of indebtedness, which also allowed us to describe the relationship towards risk, which is a phenomenon that is observed as part of the sample of family businesses under research.

\subsection{The trustworthiness, validity and reliability of the research data}

We undertook certain steps to ensure the reliability of qualitative research (Pieper et al., 2015). In accordance with methodological recommendations (Yin, 1994), information on companies from the questionnaire was supplemented with information from publicly available databases (justice. cz and internal company documents including annual reports) in order to gain as much information as possible about the firms' operations with regard to the characteristics of a family business. After adding information from the publicly available sources, it was discovered that the sample was sufficiently heterogeneous (Eisenhardt, 1989) to identify the differences in the boards of family businesses without distortion caused by external influences. The sample of firms differed in size, industry focus, length of the firm's existence, representation of family members in company management, and gender. All information obtained from the theoretical study were incorporated into the semi-structured interview, which was supplemented by information from the questionnaires carried out in the first stage of the research, in order to meet the conditions for the complementarity of data according to Downward \& Mearman (2007).

Table 2. Framework for staging the research

\begin{tabular}{|c|c|c|c|c|}
\hline \multirow{2}{*}{$\begin{array}{l}\text { Research } \\
\text { activity }\end{array}$} & \multirow{2}{*}{$\begin{array}{l}\text { Identification of } 432 \\
\text { firms including } 91 \\
\text { family firms (Albertina } \\
\text { database) }\end{array}$} & \multirow{2}{*}{$\begin{array}{l}\text { Formulation } \\
\text { of RQ and } \\
\text { choice of } 4 \\
\text { family firms }\end{array}$} & \multicolumn{2}{|c|}{$\begin{array}{l}\text { Monitoring characteristics of chosen } \\
\text { family firms }\end{array}$} \\
\hline & & & Case analysis & $\begin{array}{l}\text { Synthesis } \\
\text { of research } \\
\text { conclusions }\end{array}$ \\
\hline Time line & $\begin{array}{llll}2006 & 2007 & 2008 & 2009\end{array}$ & 2010 & $\begin{array}{llll}2011 & 2012 & 2013 & 2014\end{array}$ & 2015 \\
\hline
\end{tabular}

Source: authors 


\section{RESULTS}

The information presented in the research was obtained in several ways; firstly, data was gathered from public databases which were then supplemented by questionnaires and information from interviews and from visits to the companies. The results are presented in the following way - there is a brief introduction to each family firm detailing the history and focus of the business. This is followed by a description of the board's composition, the parameters of nepotism, paternalism, relationship towards risk, orientation towards sustainability or profit, and centralization. Lastly, there is a comparison of the parameters relating to the family businesses and an evaluation of their impact on the basic economic indicators achieved by the individual family businesses.

\subsection{Phase 1. Case analysis}

\subsubsection{Case study: Family business A.}

Board composition - the management of the family business has been in the hands of two siblings since 1991 to the present day. Therefore, there have been no external managers although the firm has 64 employees. The company has two directors and two partners. The board is a family structure consisting of two brothers. The older brother has a $50.5 \%$ share and the younger $49.5 \%$. At the same time, both of them are directors and partners. Both directors are authorized to act independently on behalf of the company and approve contracts in the name of the company.

\subsubsection{Characteristic phenomena}

Nepotism - the firm's founders are also its owners. No other family members work for the firm. Therefore, there has been no nepotism in the company so far. As the owners' children are still young, there have been no company successors.

Paternalism - the owners of the family business (two brothers) do not want to give up their ownership and executive rights even in the future - and so their behaviour can be labelled as paternalist. This has been documented by their statement: "As the owners of the firm we want to know everything that is happening in the company, because my brother's family and mine all live within the company grounds. We also personally supervise production, we attend all of the company's exhibitions and presentations, and we personally negotiate with our supplier" (quoted: the older brother, a partner as well as director).

Centralization, orientation towards sustainability - this paternalism is also evident in the strong centralization and mistrust towards external employees among the company's top management, an aversion to risk and a significant focus on the company's sustainability. This has also been documented in a specific statement: "We've had some bad experience with external employees. Once we tried to employ a manager as the company economist and it didn't turn out well. For us, it's a big risk to hand over that responsibility to someone from the outside. It's been the same with some software applications which were supposed to make the management and running of the company more efficient. Finally, my brother and I decided that it was better to keep the firm at such a size that we could manage it ourselves" (quote: the older brother, a partner as well as director).

\subsubsection{Case study: Family business B.}

Board composition - since the start, the siblings have had equal ownership share of the company. The sister and three brothers are directors and partners of the firm and 
each has a $25 \%$ share. The directors negotiate and approve contracts in the company's name. At present the company has three subsidiaries which are fully supervised by family members. The company owners, who are also its managers, actively participate each day in all of the firm's operations, which means they are fully aware of how the firm is run.

\subsubsection{Characteristic phenomena}

Orientation towards sustainability, centralization - in the words of one of the company managers, the company founder's daughter, the goal of the firm is to: "Maintain a stable company which is able to satisfy the needs of the family. Therefore, the firm's management isn't planning to expand into foreign markets. The goal is to keep the firm at such a size that the family is able to fully manage it." The exercise of ownership and executive rights in the family business is firmly under family control. In 2006, the company founder reduced his activity in the company as he had reached the retirement age. He was subsequently appointed the company's director emeritus for life with the right to participate in all of the company's activities as adviser (Annual company report, 2006). Naturally, he also remains one of the company's directors. Therefore, the leadership of the firm transferred smoothly to the founder's children - four siblings.

Nepotism can be partly seen in this family business mainly due to external reasons. The company employs the wives of two of the founders. According to one of the company directors: "Over time the company also employed two of the older brothers" wives, who had problems finding work after their maternity leave. Both relatives were employed in management positions. My son also works for the firm occasionally."

The company director also added that: "Employing the two brothers' wives, who joined after their maternity leave, meant that the company acquired two very loyal employees. The family works very hard for the company, and working weekends are not an exception. All family members feel very close to the family business and would never change their job. And that goes for our children as well - whenever they work here, we try to instil in them a feeling of solidarity, loyalty and responsibility towards the firm."

Nevertheless, the interview also revealed that despite positive experiences with employees from the close family circle, the firm's management resisted employing members from the extended family. As the director stated: "Much more pressure is placed upon family members and they are under greater pressure because they stand out more amongst the staff, and the members of the extended family would find that difficult to cope with."

Paternalism in the company could be seen in the transfer of the company from its founder to his children - his daughter (at present a director) and her brothers. The company director stated that the company's original founder did not want to give up ownership of the company and is still its director emeritus in an advisory capacity and is still a company director. Paternalism can also be seen in the company through the family-based centralization of decision making and work supervision. The company tends to take on contracts from the local market which can be easily monitored, which points to an aversion towards risk and related centralization.

"The family members from the company's top management supervise all of the construction contracts that the firm is involved in. This fact also impacts the scope and breadth of company's activities. And in order to maintain the level of the quality of work, most of our contracts are carried 
out near the company headquarters. Thanks to this, we have on average a maximum of three complaints per year and these are usually down to a mistake on the part of the customer. Even in these cases we act in a professional manner and try to find a common solution to the situation" (quote: company executive).

Although all the partners have an equal share in the firm, at present the oldest daughter, i.e. the director, has the decisive rights in the family business.

\subsubsection{Case study: Family business $C$.}

Board composition - at present the company has three directors: the firm's founder, his son and daughter. The siblings are also partners with a $50 \%$ share of the company. The directors represent the company independently. The board has no other members. In this company the exercise of ownership and executive rights is delegated mainly to the son of the original founder, who holds the position of production director and is responsible for the running of the whole company. Therefore, the firm transferred smoothly from father to son. At present, the son of the original founder manages the company, despite the fact that the representatives on the board are also his sister and the original founder - their father. The director's wife also works for the company. All of the firm's activities are concentrated in one facility only.

\subsubsection{Characteristic phenomena}

Relationship towards risk, centralization - the firm's aversion to risk is reflected in the stability of its suppliers and customers, who are also all family businesses. They have known each other for a long time and the companies have maintained their longterm collaboration despite having higher prices than the competition. Their customers also greatly appreciate the fact that the firm has remained in the hands of the family. The aversion to risk is evidently the result of the responsibility which comes from the awareness of owning a family business. It is evident that the firm's management is aware of this responsibility and that they try their utmost to ensure the firm prospers. The company management does not plan any changes to the ownership structure in the future. As they state: "We want to keep the firm in the family's hands. We couldn't imagine the firm being run by anyone else. This is why we're not considering radical expansion" (quote: daughter of the original founder).

Orientation and sustainability - the emphasis on stability is also apparent in the ownership structure which the firm does not intend to change. At present they describe themselves as being a stable firm with a good reputation and they would also like to keep this status in the future. The focus on company stability is also reflected in their unwillingness to enter into new markets. The company prefers to focus on expanding the choice for its existing customers. The director (the daughter of the company's founder) stated that: "We want to keep the business in family hands and avoid highrisk activities, so we stress the stability of both the buyers and the suppliers."

Nepotism - nepotism in the company is particularly obvious in the case of the founder's daughter who became the head accountant. She originally studied in a different field and worked outside of commerce. However, after a two-year training she joined her parents' company, where she still works. The founder's son was trained in the family business's commercial enterprise, after which he also joined the family business as the technical and production director. One interesting aspect was the employment of a family member - an uncle, as the firm's locksmith. The cooperation with family members at 
lower positions was not successful and the problems at work were also transferred to the family life, which led to this member of the family leaving the company.

Paternalism - paternalism in this company was seen mainly through the attempt to keep the firm in the hands of the family, which was reflected in the family's centralizing activities. The founder's son and daughter characterized the management of the family business as follows: "We try to always give $100 \%$. The firm is everything to us and we try to do as much as we can for it." The business is everything for the family, and efforts to keep it sustainable are the management's priority. This is reflected in their aversion to risk. The current manager of the firm and decision-making executor - the founder's son- has an overview of all of the firm's activities and makes the most important decisions without significant interference from other family board members. There is, therefore, a high degree of centralized decision-making within the family business. Nevertheless, according to the founder's daughter, currently a company director, "it isn't possible for the firm to operate without their presence." This has its negative aspects, such as the difficulty in taking long holidays. At the beginning, the company management spent 12 to 14 hours a day at work including weekends. The heavy workload only began to lessen when the company became stable. As stated by the director: "Even today my brother spends all day at work trying to do everything possible for the firm. He hardly ever rests. There have been so many times when I've been reluctant to go on holiday, leaving him to stay and look after the firm. He lives for the firm. It means everything to him." It was also discovered that the founder's son instilled family values into the business. One example of introducing family values to the firm was a ban on smoking - as no one in the family smoked, the whole company became a non-smoking one.

\subsubsection{Case study: Family D.}

Board composition - in addition to two family executives, father and son, there are another two executives who are not part of the family and are external employees working on the board. Over recent years there have been several changes to the ownership structure, when one of the original founders remained the majority partner with a $51 \%$ share. The other company founder has a share of $33 \%$ and the last one owns 9 of the company $\%$, and none of them is related to the original owner. The remaining shares are divided between the external members of the board. In 2009, the executive's father stopped working for the company and it was handed over from one generation to the next. However, the remaining two executives are still part of the family business.

In 2015, the original family business became a non-family one. Therefore, since 2015 there have been no family connections. Due to the fact that the founder's son was present from 2009 to 2015 when the data and indicators were collected, the firm can be considered to be a family one over the period monitored. It became a nonfamily business in 2015 when the data used for this research had already been collected and analysed. Therefore, the departure of the original founder's son did not affect research results, though from the perspective of providing all relevant data, the authors considered it important to mention this fact.

\subsubsection{Characteristic phenomena}

Low-level centralization - the firm has two independent facilities which are not completely autonomous units. Nevertheless, according to the company management, centralized decision making is at a low level, which is due to the fact that employees 
at a lower level decide independently on the most important matters concerning construction contracts.

Relationship towards risk, orientation towards profit - the relationship towards risk in the family business is reflected in the presence of high-risk activities. As the director of the company (the founder's son) stated: "Many of our activities at the moment are high-risk. For example, we want a contract to modernize blocks of flats in Mongolia." Although these were highrisk activities, the management attempted to secure guarantees from the Mongolian government and a Czech bank, Komerční Banka. "Our company is also struggling with large debts amounting to 135.7 million CZK, which represents half of the company's assets. Unfortunately, the company is in the bankruptcy procees. This is why we often use revolving credit in order to operate." (quote: company director, founder's son). Due to the company's less than positive financial situation, the company also uses loans to finance contracts abroad.

Nepotism - it is possible to identify nepotism in the company with the employment of the original founder's son, who himself stated that he had originally shown no interest in joining the firm. However, circumstances led him to being employed in one of the lower positions when he was 19 . He, therefore, lacked any proper qualifications or further education. He gradually learned about all of the firm's activities, so that by 2015 he became the director of the sales-administration division as well as a company executive. ${ }^{1}$

Paternalism - the firm did not exhibit any particularly paternalistic behaviour. According to the company's owner, there was no obvious centralized decision-making by the family, which is demonstrated by the fact that lower-level employees could make their own decisions about important issues.

\subsection{Phase 2: Synthesis of results}

When evaluating the results and carrying out their synthesis, it was possible to form a notional image that profiled similarities and differences between individual family businesses. As is clear from Table 3, it is possible to present the basic profiles between the family businesses.

Table 3. Results

\begin{tabular}{|l|c|c|c|c|}
\hline & Firm A & Firm B & Firm C & Firm D \\
\hline $\begin{array}{l}\text { Number of non-family top managers (in the } \\
\text { year 2015) }\end{array}$ & 0 & 0 & 0 & 2 \\
\hline Historical continuity dating before 1948 & yes & no & no & no \\
\hline $\begin{array}{l}\text { Orientation towards profit/maintenance of } \\
\text { company }\end{array}$ & maintenance & maintenance & maintenance & profit \\
\hline Level of centralization & high & high & high & low \\
\hline Relationship towards risk & aversion & aversion & aversion & inclination \\
\hline Nepotism & no & yes & yes & yes \\
\hline Paternalism & no & yes & yes & no \\
\hline Succession & No & Yes & Yes & Yes \\
\hline Gender diversity in the Board-female & no & yes & yes & no \\
\hline $\begin{array}{l}\text { ROA indicator (CAGR) in years 2006 - 2015 } \\
\text { (graph 3) }\end{array}$ & -1.86 & -0.25 & -0.12 & -2.31 \\
\hline Debt & $13.95 \%$ & $62.83 \%$ & $49.06 \%$ & $87.75 \%$ \\
\hline
\end{tabular}

Source: authors according to internal materials of the observed companies

\footnotetext{
Note: in 2015 the son left the firm to pursue other activities
} 
The following characteristic phenomena could be observed in the family businesses with various board compositions, all of which were established during the transition economy. When interpreting the results some caution is required concerning external members of the board. There was only one company which had board representatives who came from outside the family. The orientation towards company sustainability, which is typical for this type of business, was evident in three of the companies under observation. There was only one case which had a different orientation towards profit, where external members of the board were also represented.

There was also a greater level of centralization connected with all of the companies which stated their intention of remaining a family business. The family businesses also showed a general aversion towards risk. As we discovered, the representation of external board members can reduce risk aversion. The results examining nepotism and paternalism may have been ambiguous, but they were all the more interesting for it. These findings pointed to the occurrence of both characteristics in only some of the family businesses. The results concerning the representation of women on the board showed that women were actively involved in the board if they were part of the family that managed the firm.

Companies that do not have external representatives on the board declared the strategy employed as defensive, as well as centralization and aversion towards risk.

The impact which these characteristic phenomena of family businesses, in the form of the strategies they employ, has on the strategic adaptability and direction of the companies, is measured by the economic results in individual years in order to compare the results.

\subsubsection{Economic results - ROA in individual years}

Graph no. 1 presents the development of economic indicator for the return on assets of family businesses. As is clear from the graph, firms A, B and C are stable businesses. Over the period monitored, family businesses $\mathrm{B}$ and $\mathrm{C}$ showed positive economic activity through their positive economic results and the corresponding ROA indicator. Family business A achieved a balanced economic activity when the economic results for the last three years were completely balanced between income and expenses. Table 3 also shows how cautious family businesses $\mathrm{A}$ and $\mathrm{C}$ are in terms of debt and their attitudes to risk. On the other hand, firm B has higher debt despite claiming to be averse to risk. Family business D did not achieve very positive economic results; it describes itself as being positive towards risk and is quite heavily in debt. In terms of their long-term activities, the family businesses which demonstrated characteristic phenomena such as paternalism, nepotism, orientation towards company sustainability, aversion to risk and centralization, were better off in the assessment of their economic situation. The impact of their long-term behaviour can be compared with the company where the characteristic phenomena were not assessed more positively. These companies were able to employ strategies which withstood negative external phenomena such as the economic crisis. The characteristic behaviours which determined their strategies during the period under observation were evidently the reason why the impact on their current direction had positive results. 
Graph 1. ROA in individual years of cooperating family firms

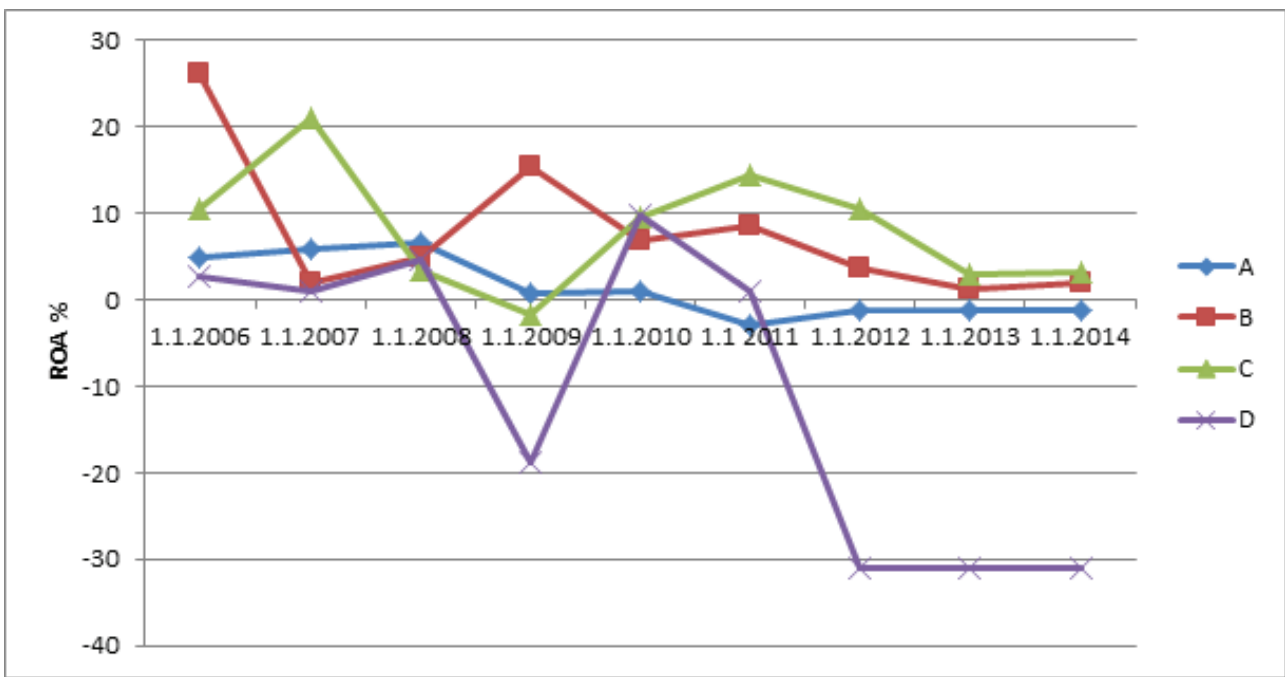

Source: authors according to internal materials of the observed companies

\section{CONCLUSION}

Contemporary theoretical approaches address the issue of the influence of family-business board composition from the perspective of strategic adaptability and the representation of external members (Berrone et al, 2010; Zellweger et al., 2013; Ponomareva \& Ahlberg, 2016; McKee et al., 1989). There has been little research into gender diversity in family businesses and its influence on strategic adaptability and it tends to focus on strategies employed rather than strategic adaptability (Cesaroni \& Sentuti, 2014). There has been no research into the influence of transition economy from the perspective of board composition - i.e. the representation of external members and gender diversity - on the strategic adaptability of companies. This longitudinal study of four family businesses provides valuable information on family business in a transition economy.

The results of research into these companies showed that if there is gender diversity on the board of a family business established in the transition economy (Adams \& Funk, 2011), if there is also equal asset share in the firm and no external members (Berrone et al., 2010; Zellweger et al., 2013), then there is a higher degree of strategic adaptability. The behaviour of boards of family businesses A, B and $\mathrm{C}$ was characterised by the phenomena of nepotism, paternalism, orientation towards sustainability, risk aversion, and centralization, and they were able to adapt to the environment substantially better than the company that did not meet these conditions. The research and the results which were achieved can also be viewed in the context of the economic crisis (Gallizo et al., 2014), which also had an impact on Czech family businesses. It was thanks to strategic adaptability in the face of these negative external conditions that family businesses exclusively in the hands of the family and exhibiting gender diversity coped better with this obstacle. There were also interesting findings concerning the differences between family members who became managers and family members who became employees. The 
difference could be the result of the responsibility of managers who are also business owners so they are more motivated to sustain the business for their successors.

Despite all of these findings, we are naturally aware of research limitations, particularly for measuring a company's success using ROA and indebtedness indicators. The sample is also limited in terms of the industry sector as only the manufacturing industry is represented, although it should be stressed that it is the dominant sector in the Czech Republic's economy. It is also necessary to point out that only family businesses from the Czech Republic were selected and, therefore, it is impossible to generalize these findings for countries in a transition economy, specifically in Central and Eastern Europe. Another limitation was caused by the lack of willingness of some companies to be part of the research, which was relatively complex and long-running.

\section{References}

1. Adams, R., \& Funk, P. (2012). Beyond the Glass Ceiling: Does Gender Matter? Management Science, 58(2), 219-235.

2. Aguilera, R. V., \& Cuervo-Cazurra, A. (2004). Codes of good governance worldwide: what is the trigger? Organization Studies, 25(3), 415 - 443.

3. Anderson, R. C., \& Reeb, D. M. (2004). Board composition: Balancing family influence in S\&P 500 firms. Administrative Science Quarterly, 49(2), 209-237.

4. Banalieva, E. R., Eddleston, K. A., \& Zellweger, T. M. (2015). When do family firms have an advantage in transitioning economies? Toward a dynamic institution based view. Strategic Management Journal, 36(9), 1358-1377.
Last limitation was the fact that we looked for companies that had been present on the market for some time and had a healthy economic situation, so the results represent only successful family firms.

Nevertheless, we can point to undisputed benefits from this study relating in particular to the acquisition of information on the development of family businesses in post-transition economies, specifically the findings on the family firms board composition and sustainability and ability of these firms to withstand unfavourable market conditions.

In light of these findings, further research could focus on family businesses from the viewpoint of shared information (Gatarik \& Born, 2017), specifically the influence of the ageing board and its influence on the strategic adaptability of family businesses.

5. Bellow, A. (2003). In praise of Nepotism. Atlantic Monthly, 292(1), 98-105.

6. Berrone, P., C. Cruz, Gomez-Mejia, L.R., \& Larazza-Kintana, M. (2010). Socioemotional wealth and corporate responses to institutional pressures: Do family-controlled firms pollute less? Administrative Science Quarterly, 55(1), 82-113.

7. Bettinelli, C. (2011). Boards of directors in family firms: An exploratory study of structure and group proces. Family Business Review, 24(2), 151-169.

8. Breton-Miller, L., \& Miller, D. (2015). The arts and family business: Linking family business resources and performance to industry characteristics. Entrepreneurship Theory and Practice, 39(6), 1349-1370. 
9. Breton-Miller, L., \& Miller, D. (2006). Why do some family businesses out compete? Governance, long-term orientations, and sustainable capability. Entrepreneurship theory and practice, 30(6), 731-746.

10. Brunninge, O., Nordqvist, M., \& Wiklund, J. (2007). Corporate governance and strategic change in SMEs: The effects of ownership, board composition and top management teams. Small Business Economics, 29(3), 295-308.

11. Carney, M. (2005). Corporate governance and competitive advantage in family controlled firms. Entrepreneurship theory and practice, 29(3), 249-265.

12. Cesaroni, F. M., \& Sentuti, A. (2014). Women and family businesses. When women are left only minor roles. The History of the Family, 19(3), 358-379.

13. Coff, R. W., Coff, D. C., \& Eastvold, R. (2006). The knowledge-leveraging paradox: How to achieve scale without making knowledge imitable. Academy of Management Review, 31(2), 452-465.

14. Collin, S. O. Y., \& Ahlberg, J. (2012). Blood in the boardroom: Family relationships influencing the functions of the board. Journal of Family Business Strategy, 3(4), 207-219.

15. Corbetta, G. , \& Salvato, C. (2004). Self-serving or self-actualizing? Models of man and agency costs in different types of family firms: A commentary on "Comparing the Agency Costs of Family and Non family Firms: Conceptual Issues and Exploratory Evidence. Entrepreneurship Theory and Practice, 28(4), 355-362.

16. Čornej, P.et al. (1992). Dějiny zemí koruny české I. Paseka: Praha.
17. De Massis, A., \& Kotlar, J. (2014). The case study method in family business research: Guidelines for qualitative scholarship. Journal of Family Business Strategy, 5(1), 15-29.

18. Downward, P., \& Mearman, A. (2007). Retroduction as mixed-methods triangulation in economic research: reorienting economics into social science. Cambridge Journal of Economics, 31(1), 77-99.

19. Eisenhardt, K. M. (1989). Building theories from case study research. Academy of Management Review, 14(4), 532-550.

20. Fama, E. F. (1980). Agency Problems and the Theory of the Firm. The journal of political economy, 88(2), 288-307.

21. Fama, E. F., \& Jensen, M. C. (1983) Separation of ownership and control. The Journal of Law \& Economics, 26(2), 301-325.

22. Gallizo, J. L., Moreno, J., \& Sanchez, L. (2014). Which companies have better weathered the crisis, family firms or non-family firms?. Intangible Capital, 10(4), 766-797.

23. García-Ramos, R., \& García-Olalla, M. (2011). Board characteristics and firm performance in public founder-and no founder-led family businesses. Journal of Family Business Strategy, 2(4), 220-231.

24. Gatarik, E., \& Born, R. (2015). Managing network economies: the competitive advantage of commons as ecosystems of innovation. Journal of Organisational Transformation \& Social Change, 12(3), 287-307.

25. Gatarik, E., \& Born, R. (forthcoming): Organizational sustainability: an epistemological investigation of business continuity management 
practice in an Austrian SME. Journal of Organizational Transformation \& Social Change.

26. Gomez-Mejia, L. R., Nunez-Nickel, M., \& Gutierrez, I. (2001). The role of family ties in agency contracts. Academy of Management Journal, 44(1), 81-95.

27. Jaskiewicz, P., Uhlenbruck, K., Balkin, D. B., \& Reay, T. (2013). Is nepotism good or bad? Types of nepotism and implications for knowledge management. Family Business Review, 25(2), 121-139.

28. Kets de Vries, M.F.R. (1993). The dynamics of family controlled firms. The good and the bad news. Organizational Dynamics, 21(3), 59-71.

29. Koiranen, M.

(2002). Entrepreneurialism, managerialism and paternalism as clashing ideologies in family business systems. ARPENT: Annual Review of Progress in Entrepreneurship, 2(1), 299-310.

30. Lane, S., Astrachan, J., Keyt, A., \& McMillan, K. (2006). Guidelines for family business boards of directors. Family Business Review, 19(2), 147-167.

31. Lukeš, M., \& Nový, I. (2005). Psychologie podnikání. Management Press, Praha.

32. Matusik, S. F., \& Hill, C. W. (1998). The utilization of contingent work, knowledge creation, and competitive advantage. Academy of Management Review, 23(4), 680-697.

33. McKee, D. O., Varadarajan, P. R., \& Pride, W. M. (1989). Strategic adaptability and firm performance: a marketcontingent perspective. The Journal of Marketing, 53(3), 21-35.

34. Miles, M. B., \& Huberman, A. M. (1994). Qualitative data analysis: An expanded sourcebook. Sage, London.

35. Miller, D., Breton-Miller, L., \& Lester, R. H. (2011). Family and lone founder ownership and strategic behaviour: Social context, identity, and institutional logics. Journal of Management Studies, 48(1), 1-25.

36. Mussolino, D., \& Calabrò, A. (2014). Paternalistic leadership in family firms: Types and implications for intergenerational succession. Journal of Family Business Strategy, 5(2), 197-210.

37. Nelton, S. (1998). The Bright side of nepotism. Nation's Business, 86(5), $72-73$.

38. Nonaka, I. (1994). A dynamic theory of organizational knowledge creation. Organization Science, 5(1), 14-37.

39. Odehnalová, P. (2011). Přednosti a meze rodinného podnikání. Brno: Masarykova Univerzita.

40. Pieper, T. M., Smith, A. D., Kudlats, J., \& Astrachan, J. H. (2015). The persistence of multifamily firms: Founder imprinting, simple rules, and monitoring processes. Entrepreneurship Theory and Practice, 39(6), 1313-1337.

41. Ponomareva, Y., \& Ahlberg, J. (2016). Bad governance of family firms: The adoption of good governance on the boards of directors in family firms. Ephemera, 16(1), 53.

42. Shleifer, A., \& Vishny, R. W. (1997). A survey of corporate governance. The Journal of Finance, 52(2), 737-783.

43. Smallbone, D., \& Welter, F. (2001). The distinctiveness of entrepreneurship in transition economies. Small Business Economics, 16(4), 249-262.

44. Sten, J. (2007) What is a business family? Electronic journal of family business studies, 1(2), 168-185.

45. Suchánek, P., M. Sedláček, J. Špalek, 
\& P. Štamfestová. (2001). Kvalita jako faktor konkurenceschopnosti podniku. 1. vyd. Brno: Masarykova univerzitaISBN 978-80-210-5688-6.

46. Tagiuri, R., \& Davis, J. (1996). Bivalent attributes of the family firm. Family Business Review, 9(2), 199-208.

47. Yin, R. K. (1994). Discovering the future of the case study method in evaluation research. Evaluation Practice, 15(3), 283-290.
48. Zellweger, T. M., Nason, R. S., Nordqvist, M., \& Brush, C. G. (2013). Why do family firms strive for nonfinancial goals? An organizational identity perspective. Entrepreneurship Theory and Practice, 37(2), 229-248.

49. Žídek, L. (2006). Transformace české ekonomiky.1989 - 2004. Praha: C.H.Beck.

\section{SASTAV KORPORACIJSKOG ODBORA U OBITELJSKIM PODUZEĆIMA: DOKAZI IZ ČEŠKE REPUBLIKE}

\section{Sažetak}

U ovom se radu istražuje problematika sastava korporacijskog odbora u obiteljskim poduzećima, osnovanim u Češkoj Republici u 1990-tim godinama, nakon 40 godina potiskivanja privatnih poduzeća od strane socijalističkog režima. Do sada nije bilo raspoloživog istraživanja proizvodnog sektora u Češkoj Republici s aspekta sastava odbora, tj. zastupljenosti vanjskih članova $i$ rodne raznolikosti, uključivši $i$ karakteristike ponašanja odbora u obiteljskim poduzećima i njihovu stratešku prilagodljivost. Ovo longitudinalno istraživanje četiri obiteljska poduzeća pruža značajne informacije, koje se još nisu analizirale u kontekstu sastava odbora u proizvodnom sektoru. Rezultati intervjua, provedenih u ovim poduzećima, pružaju zanimljive spoznaje o pozitivnom utjecaju rodne raznolikosti i ekskluzivnom zastupanju članova obitelji u odboru na stratešku prilagodljivost te utjecaj na tekuće usmjerenje poslovanja. Rezultati rada također pokazuju da su obiteljska poduzeća, koja ispunjavaju navedene uvjete, sposobnija za suočavanje s negativnim vanjskim utjecajima, što se, u ovom slučaju, odnosi na financijsku krizu.

Ključne riječi: sastav odbor, obiteljska poduzeća, tranzicijsko gospodarstvo, rod, nepotizam, paternalizam, strateška prilagodljivost 